Jahangirnagar University J. Biol. Sci. 8(1): 75-82, 2019 (June)

\title{
Prevalence and abundance of insect pests in stored pulses collected from two local markets of Dhaka city
}

\author{
Tangin Akter*, Shanjida Sultana, Mehjabin Rahman, Md. Reaz Mahmud and \\ Shefali Begum \\ Department of Zoology, University of Dhaka, Dhaka-1000, Bangladesh
}

\begin{abstract}
Prevalence and abundance of stored grain insect pests in four varieties of pulses i.e. Lens culinaris, Pisum staivum, Cicer arietinum collected from two markets of Dhaka city were recorded. Nine species of insect pests, viz. Sitophilus oryzae, Tribolium castaneum, Callosobruchus chinensis, C. maculatus, Rhizopertha dominica, Oryzaephilus surinamensis, Liposcelis entomophila, Sitotroga cerealella, and Formica sp., were recorded throughout the study. The percentage of weight-loss was higher (7.54) in those pulses which were highly infested by pests. Highest pest population was observed during May to June (753). However, Sitotroga cerealella were found only in November to December of the study period. The maximum species richness (7) was observed in Green gram and Chickpeas samples, but the minimum species evenness was observed in Green gram (0.6969) and maximum in Red lentil (0.9886).
\end{abstract}

Key words: Prevalence, Abundance, insect pests, stored pulse, Dhaka city

\section{INTRODUCTION}

Insects are known to be the most successful and diverse animals on earth and are closely associated with our lives and affect the welfare of humanity in diverse ways (Chakravarthy, 2015). A huge number of pest species is associated with stored commodities. In a store, one may expect a permanent occurrence of many pest species (Stejskal et al., 2002). Insect infestation occurs in stored grains and grain products to variable extent depending upon the storage conditions in developing countries (Bhargava \& Kumawat, 2010). In addition, they transfer bacteria and microscopic fungi of pathogenic importance. (Hurbert et al., 2004).

Pulses contain $20-30 \%$ of protein, which is almost three times higher than that found in cereals (Ahmad, 1984). Cereals and pulses have great biological and nutritional value in developing countries (Arthur \& Throne, 2003; Babu et al., 2003). Pulses are generally subject to long-term storage (Tiwari et al., 2011) and the storage conditions, such as time, temperature and moisture content induce physicochemical and biological changes leading to significant effect on the nutritional composition, germination and longevity (Hentges et al., 1991; Menkov, 2000).

In Bangladesh, stored pulse insects belong to five orders, of which the Coleoptera and Lepidoptera are the most important (Kabir, 1989). Among the other three orders, the

\footnotetext{
*Corresponding author. Email: aktertl@yahoo.com
} 
Hymenoptera are most abundant, while the Diptera and Hemiptera are of minor importance (Kabir, 1989). Anonymous (1984) reported that in storage, a maximum infestation level by pulse beetles (C. chinensis, and C. maculatus) may reach upto $98.4 \%$ in mung bean, $72.97 \%$ in khesari (Lathyrus sativus L.), $64.33 \%$ in chickpea, $46.48 \%$ in lentil (Lens culinaris), $29.08 \%$ in black gram, and $4.0 \%$ in field pea (Pisum sativumarvense) during 6-8 months of storage.

Pests are dynamic in nature and succession of pests occur according to agro-ecosystem (Sekhar et al., 1991). To develop economically feasible, ecologically sound, and socially acceptable pest management strategies detailed information about the pest complex, the status and the sequence of appearance of the pest, the losses and type of damages are of great importance (Bijjur \& Verma, 1995). Therefore the objectives of the present study was to identify the insect pests from the stored pulses, to study the succession of insect pests and to find out the diversity index and evenness of distribution of insect pests.

\section{MATERIAL AND METHODS}

The experiment was conducted in the Entomology Laboratory, Department of Zoology, University of Dhaka from May to December 2016 at $28 \pm 4^{\circ} \mathrm{C}$ temperature and $70 \pm 4 \%$ relative humidity. Stored pulses were collected from two different markets (Kacha bazaar of Anandabazar and Newmarket Kacha bazaar) of Dhaka city. Four different varieties of pulses were used and the varieties of pulses were: Moshur or Red lentil (Lens culinaris), Split pea (Pisum staivum), Chickpeas (Cicer arietinum) and Mung or Green gram (Vigna radiata). Two hundred fifty grams of each type of pulses were collected every month from both the markets.

Sampling of grain, identification and counting of insect pests: Random sampling method was used for the selection of pulses. The same type of pulse was collected from both the market and kept in plastic jars and were brought back to the laboratory.

The collected pulse containing pests were taken in one petridish. Then the insect pests from the pulses were separated to another petridish and the pests were separated according to their species. At last the insect pests of various species were counted separately. The identification of various pest species was conducted by observing the external morphology of the pest insects using magnifying glass and light microscope. The insect species were identified following taxonomic key of Borror et al. (1976), and Cotton (2007).

Weight loss calculation: The weight of each type of pulses were measured initially by using an electric balance- KERN \& Sohn GmbH, KB 360-3N. The samples were then kept in the plastic jars for one-month observation. After one month, the samples in the plastic jars were measured again. The weight loss (\%) was calculated by using the formula suggested by Parkin (1956): 


$$
\begin{aligned}
& \text { Weight loss } \%=\frac{(W 1-W 2) \times 100}{W 1} \\
& \text { W1= Initial weight of sample } \\
& \text { W2= Final weight of the sample after one month }
\end{aligned}
$$

Abundance, richness and diversity index estimation: Quantitative estimation of pest species was made using the data derived from the study. Species diversity was computed based on Shannon \&Wiener (1963) formula. Abundance and richness of species was also calculated (Southwood, 1978). Diversity index $(\mathrm{H})$ depends on both the number of species present and the abundance of each species and calculated as follows:

$$
\begin{aligned}
& \mathrm{H}=\Sigma \text { pi } \log 2 \text { pi (where } \mathrm{H}=\text { Diversity index) } \\
& \mathrm{pi}=\text { ni/N } \\
& \text { (ni }=\text { number of individuals of each species in the sample } \\
& \mathrm{N}=\text { Total number of individuals of all species in the samples). } \\
& \mathrm{E} \text { (Evenness or equitability) }=\frac{H}{\ln S} \\
& \text { Where, } \mathrm{S}=\text { total number of species in the community (richness) }
\end{aligned}
$$

Abundance of pest species population was calculated by the sum of all available species in different samples. Species richness was estimated by the variety of insect pest species in four different samples.

\section{RESULTS AND DISCUSSION}

Total 9 species of insect pests viz Sitophilus oryzae, Tribolium castaneum, Callosobruchus chinensis, C. maculatus, Rhizopertha dominica, Oryzaephilus surinamensis, Liposcelis entomophila, Sitotroga cerealella, and Formica sp. were identified during the experiment. Among them six were under the order Coleoptera, and the other three belong to the order Psocoptera, Lepidoptera and Hymeoptera.

Monthly weight loss percentage: The weight loss percentage fluctuated with the number of insects. When the number of pests was high, then the weight loss percentage was also high. In case of pulse samples which was collected from Anandabazar, the weight loss percentage the lentil pulse was high $(7.54,2.74,6.01)$ from May to October. During November and December, weight loss percentage was higher in green gram (1.48) and lower in Chickpea (0.15). The relationship curve between weight loss percentage and the number of insects fluctuated much in the varieties of pulse collected in NovemberDecember (Fig. 1a).

Among the pulse samples collected from New market, the month wise percentage of weight loss were higher (7.02) in lentil during May-June, in green gram 4.93 during JulyAugust and 5.54 in September-October, respectively and in Chickpea 2.57 during November-December. Among the eight months of experiment, the lowest percentage of weight loss was found in lentil (0.58) during November-December (Fig.1b). 


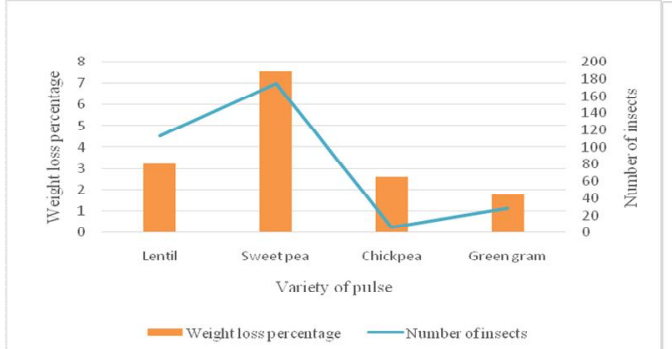

(a)

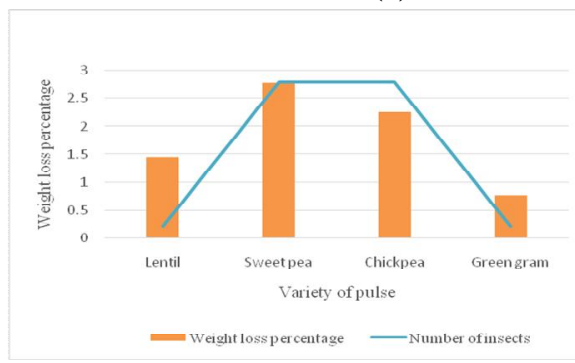

(a)

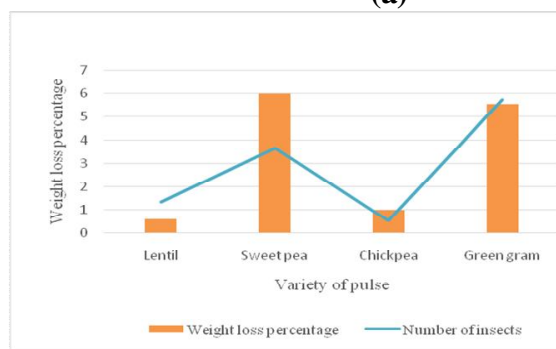

(a)

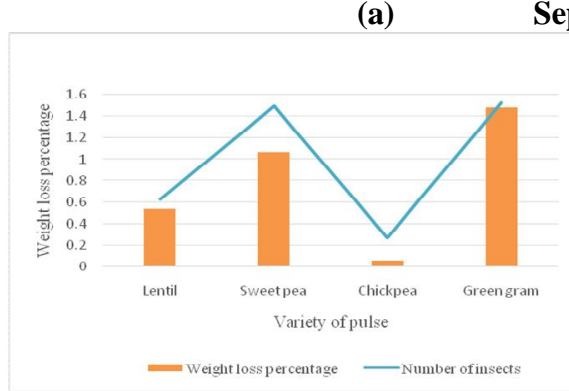

(a)

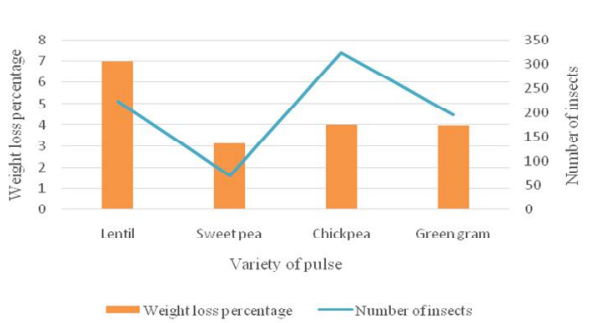

(b)
May-June, 2016

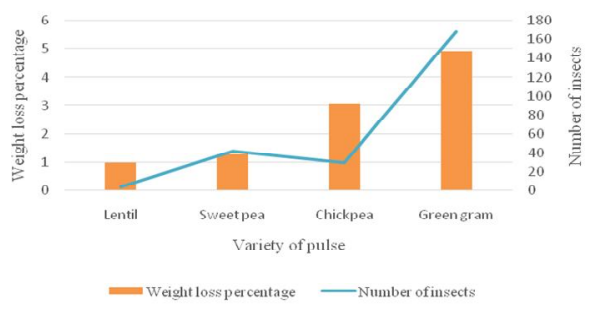

(b)
July-August, 2016

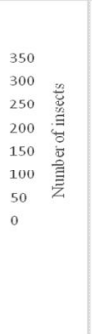

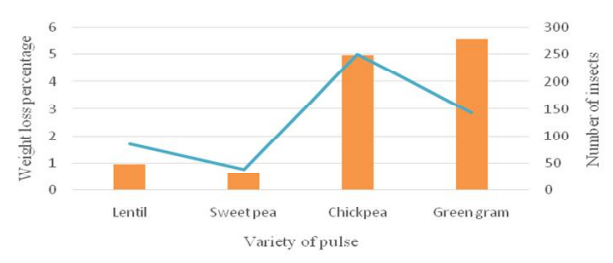

Weight loss percentage - Number ofinsects

Fig. 1. Weight loss percentages with number of insects in varieties of pulses during different storage period

Shazali (1987) experimented on the apparent and real weight losses caused by the development of Sitotroga cerealella (Olivier) and S. oryzae (L.) inside sorghum grains of two size classes. The amount of food consumed by the developing larvae of $S$. cerealella was similar in large and in small grains; in case of $S$. oryzae the amount consumption was 
decreased with the decrease of the grain size. Singh et al. (2013) also found that due to poor harvest storage and pests attack $10-30 \%$ of grains were wasted.

Succession of insect pests: Majority of these pulse samples had group of insect pests infestations. The collected samples had 9 pests, of which 6 were major pests and the other three were minor pests. The minor pests for pulse grains were Liposcelis entomophila, Rhizopertha dominica, and Formica sp. R. dominica may be considered a minor pest which mainly attacks rice grains and may be accidentally came into the pulse sample.

Highest number of $S$. oryzae (753) were recorded from the pulse samples collected during May - June, 2016, while both $O$. surinamensis (5) and T. castaneum (1) were lowest in number. In the samples of July-August, highest infestation occurred by $S$. oryzae (232) followed by T. castaneum (24). About half of the infestation was observed by $S$. oryzae (608) and other half by C. cinensis (408) in the samples of September and October. Among all the pests $S$. oryzae had been found through the whole study period (May-December, 2016) (Fig. 2). Highest pest population was observed in the samples of May to October month of the year 2016. The warm weather indicates the higher frequency of pests, while in cooler weather the abundance of pest insects was comparatively low. However, Sitotroga cerealella was found only in the collections of November-December (Fig. 2). Khokhar \& Singh (1983), documented 38 species of insect pests on pigeon pea at Hisar. They also observed the pest succession on various growth stages of the crop. Appearance of Mylobris pustulata, Helicoveppa armigera, Clavigrella gibbosa, Nezara virudula, Meruca testulalis was seen in the month of September and October.

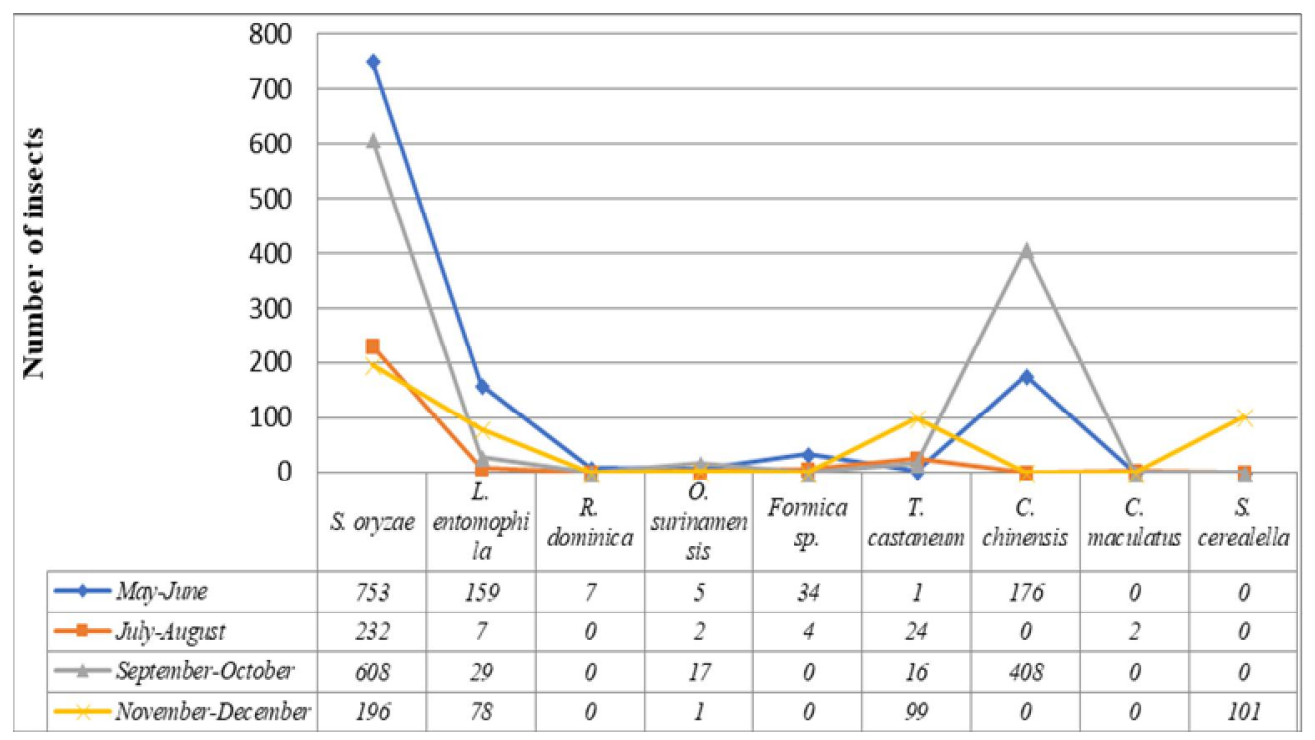

Fig. 2. Succession of insect pests in stored pulse varieties during May to December, 2016 
Species abundance, species richness and diversity index: Presence of pest species varied from pulse to pulse and also varied due to the seasonal variation. For an example, C. chinensis was only found in green gram pulse, whereas Sitotroga cerealella was found in all other three types of pulses except Chickpea. Highest abundance was observed in Sitophilus oryzae which was 1785 and lowest was in C. chinensis which was 2 (Table 1).

Table 1. Species density abundance and distribution of insect-pests in various pulses

\begin{tabular}{l|c|c|c|c|c|c}
\hline \multicolumn{1}{c|}{ Species } & \multicolumn{6}{c}{ No. of insect in different pulses } \\
\cline { 2 - 7 } & Lentil & $\begin{array}{c}\text { Sweet } \\
\text { pea }\end{array}$ & Chickpea & $\begin{array}{c}\text { Green } \\
\text { gram }\end{array}$ & Abundance & Distribution \\
\hline Sitophilus oryzae & 496 & 449 & 627 & 213 & 1785 & 4 \\
Oryzaephilus surinamensis & 4 & 16 & 3 & 23 & 46 & 3 \\
Rhizopertha dominica & 0 & 1 & 5 & 1 & 7 & 3 \\
Tribolium castaneum & 9 & 0 & 36 & 93 & 138 & 3 \\
Callosobruchus maculatus & 0 & 0 & 2 & 0 & 2 & 1 \\
Callosobruchus chinensis & 0 & 0 & 0 & 584 & 584 & 1 \\
Liposcelis entomophila & 26 & 163 & 78 & 6 & 273 & 4 \\
Sitotroga cerealella & 16 & 19 & 0 & 39 & 74 & 3 \\
Formica sp. & 5 & 15 & 3 & 15 & 4 & 38 \\
\hline
\end{tabular}

The diversity index of the four pulse varieties ranges from 1.53113-2.1704 where the highest was in Lentil and lowest was in Green gram. The Chickpea and Green gram were highest in species richness, having seven types of insect species infestation among nine species. Distribution of insects in stored pulses were more even. The value of species evenness was quite similar in Lentil, Sweet pea and Chickpea samples, but in green gram pulse it dropped to 0.69 (Table 2). The relation between diversity index and evenness showed that, the insect pests had more or less an equal distribution over the month of May to October in the four pulse grain samples, but the evenness in diversity slightly decreased in November to December.

Table 2. Species richness, abundance, diversity index of insect pests in different varieties of pulses

\begin{tabular}{l|c|c|c|c|c|c|cc}
\hline $\begin{array}{l}\text { Study } \\
\text { Sample }\end{array}$ & $\begin{array}{c}\text { Richness } \\
(\mathrm{S})\end{array}$ & $\begin{array}{c}\text { Abundance } \\
(\mathrm{N})\end{array}$ & $\begin{array}{c}\text { Coleoptera } \\
(\%)\end{array}$ & $\begin{array}{c}\text { Psocoptera } \\
(\%)\end{array}$ & $\begin{array}{c}\text { Lepidoptera } \\
(\%)\end{array}$ & $\begin{array}{c}\text { Hymenoptera } \\
(\%)\end{array}$ & $\begin{array}{c}\text { Diversity } \\
\text { index } \\
(H)\end{array}$ & $\begin{array}{c}\text { Evenness } \\
\ln S\end{array}$ \\
\hline $\begin{array}{l}\text { Lentil } \\
\text { Sweet }\end{array}$ & 6 & 556 & 50 & 16.67 & 16.67 & 16.67 & 2.17204 & 0.9886 \\
pea & 6 & 663 & 50 & 16.67 & 16.67 & 16.67 & 2.05778 & 0.9366 \\
Chickpea & 7 & 754 & 71.43 & 14.28 & 0 & 14.28 & 2.13211 & 0.970 \\
$\begin{array}{l}\text { Green } \\
\text { gram }\end{array}$ & 7 & 951 & 57.14 & 14.28 & 14.28 & 14.28 & 1.53113 & 0.6969 \\
\hline
\end{tabular}

Pinjara et al. (2017), investigated the comparative diversity of coleopteran fauna in blackgram greengram and cowpea, sampled from three different locations and the Shannon's diversity index values were ranging from 1.72 to 1.54 . They also found 8 
coleopteran families and based on relative density the curculionids and chrysomelids were dominant in pulse crops.

Therefore, understanding the percentage of weight loss, succession and abundance of stored product insect pests would help initiating suitable strategies for controlling these pests.

\section{REFERENCES}

Ahmed, E.U. 1984. Losses incurred in stored food grains by insects, PARC Grain Stprage Res. Lab. Karachi, Pakistan.

Anonymous. 1984. Annual Report 1983/84. Plant Pathology Division Joydebpur, Gazipur, Bangladesh: BARI. 90 pp.

Arthur, F.H. and Throne, J.E. 2003. Efficacy of diatomaceous earth to control internal infestations of rice weevil and maize weevil (Coleoptera:Curculionidae). J. Econ. Entomol. 96:510518.

Babu, A., Hern, A. and Dorn, S. 2003. Sources of semiochemicals mediating host findings in Callasobruchus chinensis (Coleoptera: Bruchidae). Bull. Entomol. Res. 93: 187-92.

Bhargava, M.C. and Kumawat, K.C. 2010. Pests of stored grains and their management. New India Publishing, New Delhi. 264 pp.

Bijjur, S. and Verma. S. 1995. Sequential appearance of insect pests and natural enemy complex of on Pea crop. Indian J. Entomol. 57(4): 373-377.

Borror, D.J., Delong, D.M. and Triplehorn, C.A. 1976. An introduction to the study of insects. $\left(4^{\text {th }}\right.$ ed.) Holt and Winston, New York. 852 pp.

Chakravarthy, A.K. 2015. New horizons in insect science: Towards sustainable pest management. Springer, India. $431 \mathrm{pp}$.

Cotton, R.T. 2007. Insect pests of stored grain and grain products. Daya Books. 241 pp.

Hentges, D.L., Weaver, C.M. and Neilsen, S.S. 1991. Changes of selected physical and chemical components in the development of the hard- to-cook bean defect. J. Food. Sci. 56: 436442.

Hubert, J., Stejskal, V., Munzbergova, Z., Kubatova, A., Vanova, M. and Zdarkova, E. 2004. Mites and fungi in heavily infested stores in the Czech Republic. J. Econ. Entomol. 97(6): 2144-53.

Kabir, S.M.H. 1989. Insects and mites associated with stored grain and grain products in Bangladesh. J. Asiat. Soc. Bangladesh, Sci. 15: 123-128.

Khokhar, K.S. and Singh, Z. 1983. Insect pests associated with pigeon pea at Hissar. International Pigeon pea News Letters. 2: 43-44.

Matthews, G.A. 1993. Insecticide application in the stores. Application technology for crop protection, CAB, London, pp. 305-315.

Menkov, N.D. 2000. Moistuer sorption isotherms of chickpea seeds at several temperatures. $J$. Food. Eng. 45: 189-194.

Parkin, E.A.1956. Stored product entomology (the assessment and reduction of losses caused by insects to stored foodstuffs). Annual Rev. Entomol. 1(1): 223-240.

Sekhar, J.C., Singh, K.M., Singh, R.N. and Singh, Y. 1991. Succession of insect pest on pigeonpea (Cajanus cajan (L.) Millsp.) cultivated at different maturity. Indian J. Entomol. 53(2): 316-319.

Singh, P., Satya, S. and Naik S. 2013. Grain storage insect-pest infestation-issues related to food quality and safety. Intern. J. Food Safety. 15: 64-73. 
Pinjara I.M., Purushan G. S., Meena A.K. and Swaminathan R. 2017. Diversity of coleopteran fauna in kharif pulses from three different locations of Southern Rajasthan. J. Entomol and Zool. Studies. 5(2): 616-618.

Shannon, C.E. and Wiener, W. 1963. The Mathematical theory of communication. University of Juionis Press, Urbana. 117pp.

Shazali, M.E.H. 1987. Weight loss caused by development of Sitophilus oryzae (L.) and Sitotroga cerealella (Oliv.) in sorghum grains of two size classes. J. of Stored Products Res. 23(4): 233-238.

Southwood, K.E., 1978. Substantive theory and statistical interaction: Five models. Amarican J. Sociol. 83(5): 1154-1203.

Stejskal, V., Hubert, J. and Luka, J. 2002. Species richness and pest control complexity. In: Working Group Integrated Protection in Stored Products. Proc. Of the meeting in Lisbon, Portugal, 3-5 September 2001; IOBC Bulletin. 25 pp.

Tiwari, B., Gowen, A. and Mckenna, B. 2011. Introduction in Pulse Foods: Processing, Quality and Nutraceutical Applications. Academic Press, Amsterdam, Boston, pp. 1-7. 